Сливінський О. А., Борніков А. С.

Національний технічний університет України «Київський політехнічний інститут імені Ігоря Сікорського». Україна, м. Київ

\title{
ВПЛИВ ВУГЛЕЦЕВИХ ВОЛОКНИСТИХ ПРИСАДОК НА СТРУКТУРУ ТА ТВЕРДІСТЬ НАПЛАВЛЕНОГО АУСТЕНІТНОГО МЕТАЛУ
}

Встановлено принципову можливість підвищення твердості металу ива, виконаного низьковуглецевими хром-нікель-марганцевими дротами аустенітного класу, иляхом застосування вуглецевої волокнистої присадки. Визначено вплив вуглещевої волокнистої присадки на мікроструктуру наплавленого металу. За результатами проведених експериментальних досліджень припущено, що залежність твердості наплавленого дротами типу $G 188 \mathrm{Mn}$ металу від питомої ваги внесеної вуглецевої присадки має лінійний характер та може бути описана запропонованим у роботі параметричним рівнянням. [dx.doi.org/10.29010/083.9]

Ключові слова: механізоване зварювання у суміші газів; вуглеиеві волокнисті матеріали; броньові сталі високої твердості; аустенітний електродний дріт; мікротвердість; мікроструктура.

\section{Вступ}

Для забезпечення необхідних службових властивостей листовий прокат з легованих броньових сталей високої твердості, що містять у середньому $0,26 \ldots 0,32 \%$ вуглецю, підлягає термічному зміцненню шляхом загартування 3 наступним низькотемпературним відпуском. В результаті, ці матеріали набувають структури мартенситу відпуску та мають високі показники міцності: границю плинності - не менше 1250 МПа, границю міцності більше 1450 МПа, при твердості - не нижче прибл. 50 HRC [1]. Разом із цим, підвищена загроза утворення холодних тріщин обмежує зварність цих сталей.

Стандартним заходом з попередження тріщиноутворення при зварюванні броньових сталей високої твердості є застосування електродних дротів аустенітного класу [2-4]. При цьому у шві намагаються одержати високолеговану хром-нікельмарганцеву сталь, що не потерпає поліморфного перетворення та зберігає аустенітну структуру до повного остигання зварного з'єднання. За умови призначення раціональних параметрів режиму зварювання та правильної техніки виконання зварних швів, це дозволяє уникнути утворення тріщин в зварних з'єднаннях, завдяки високому рівню пластичності металу аустенітного зварного шва та високій розчинності водню у ньому [5].

Разом із цим, застосування аустенітних зварювальних матеріалів не забезпечує рівноміцності металу зварного з'єднання, а необхідний рівень балістичної стійкості зварних вузлів досягається їх конструктивним виконанням. Одним з ефективних способів підвищення балістичної стійкості зварних швів, виконаних аустенітним електродним дротом $€$ наплавлення зміцнювальних шарів на їх зовнішню сторону. Для цього застосовуються електроди або порошкові дроти, що забезпечують високу твердість наплавленого шару [6-8]. В той же час, при проведенні ремонтно-відновлювальних робіт в польових умовах, заварювання бойових пошкоджень броньових корпусів військової техніки із застосуванням додаткових зварювальних матеріалів, які потребують попереднього прокалювання, застосування додаткової одиниці зварювального обладнання або заміни роликів механізму подавання електродного дроту, не завжди здійсненне.

Можливим альтернативним напрямком підвищення твердості й, відповідно, балістичної стійкості аустенітних зварних швів є застосування спеціальних присадок, що закладаються у розкриття крайок. В роботі [9] досліджено вплив нанорозмірних тугоплавких інокулянтів $\left(\mathrm{TiO}_{2}, \mathrm{SiO}_{2}, \mathrm{TiC}\right)$ на структуру та твердість аустенітного шва, що вводились в розплав зварювальної ванни шляхом їх попереднього нанесення на поверхню основного металу за допомогою парафінової зв'язки. Попри подрібнення первинної структури металу шва, суттєвого збільшення твердості досягнуто не було. В роботах [10-11] описано методи одержання на сталевих деталях зносостійких високовуглецевих покрить 3 високими триботехнічними властивостями, що грунтуються на використанні вуглецевих волок- 
нистих матеріалів. Вуглецеві волокна різних видів отримують за рахунок високотемпературного піролізу вихідних волокон-прекурсорів - гідроцелюлозних, з ПАН (з сополімерів акрилонітрила), нафтових або кам'яновугільних пеків. Наплавлення здійснюється штатними зварювальними матеріалами. Перед наплавленням на поверхню виробу наносять вуглецеву тканину, також використовують комбінацію вуглевмісного матеріалу і тонкого дроту з легувального матеріалу, за допомогою якого фіксують матеріал.

\section{Постановка задачі}

Метою даної роботи є дослідження можливостей підвищення твердості наплавленого металу виконаного високолегованим аустенітним дротом системи $\mathrm{Cr}-\mathrm{Ni}-\mathrm{Mn}$ шляхом застосування вуглевмісних тканих матеріалів та оцінка перспективності розробки вуглецевих волокнистих присадок (ВВП) для ремонту бойових пошкоджень броньових корпусів військової техніки.

При цьому вирішувались наступні завдання:

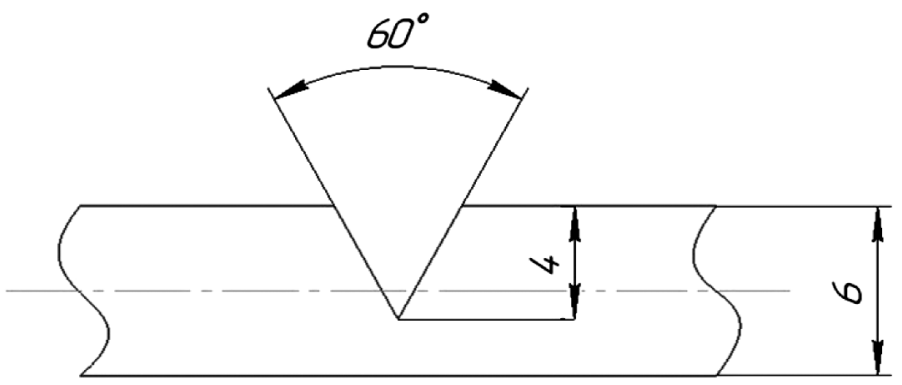

a
1. Виконувались дослідні наплавки валиків на зразки з броньової сталі високої твердості аустенітним дротом із застосуванням ВВП різного типу.

2. Досліджувалась мікроструктура та мікротвердість наплавленого металу у порівнянні з аустенітним наплавленим металом без ВВП.

3. Визначався вплив питомої ваги введених ВВП на середню твердість наплавленого металу.

\section{Обладнання та матеріали}

Наплавлення валиків виконувалось в канавки (рис. 1, а), що були попередньо вифрезеровані в пластині товщиною 6 мм з броньової сталі, хімічний склад якої наведено у табл. 1. Твердість пластини складає 52...54 HRC.

Наплавлення виконувалось в автоматичному режимі на зварювальній установці, що складається з апарату для дугового зварювання у захисному газі «Jäckle ProPULS 400» та самохідного зварювального візка «ESAB Miggytrac B501». Параметри режиму (табл. 2) залишались незмінними при наплавленні всіх 6 дослідних валиків.

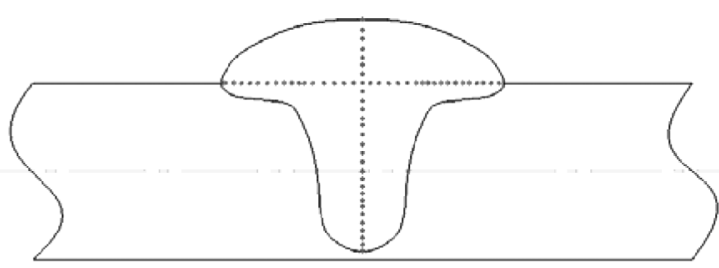

б

Рис. 1. Схема наплавлення дослідних валиків:

а) розміри канавки; б) напрямки вимірювання мікротвердості в наплавленому металі

Таблиця 1

Хімічний склад основного металу

\begin{tabular}{|c|c|c|c|c|c|c|c|c|}
\hline Елемент & $\mathrm{C}$ & $\mathrm{Si}$ & $\mathrm{Mn}$ & $\mathrm{P}$ & S & $\mathrm{Cr}$ & Mo & Домішки $(<0,04 \%)$ \\
\hline$\%$, мас. & 0,318 & 0,299 & 0,794 & 0,01 & 0,002 & 0,984 & 0,142 & $\mathrm{Nb}, \mathrm{Ti}, \mathrm{V}, \mathrm{N}$ \\
\hline
\end{tabular}

Таблиця 2

Параметри режиму наплавлення валиків

\begin{tabular}{|c|c|}
\hline Зварювальний струм, А & $150 \ldots 160$ \\
\hline Напруга дуги, В & 17,2 \\
\hline Швидкість зварювання, м/год & 11 \\
\hline Витрати газу, л/год & 12 \\
\hline
\end{tabular}

Всі валики наплавлялись електродним дротом ESAВ OK Outrod 16.95 (ДСТУ EN ISO 14343:2015 G $188 \mathrm{Mn}$ ) діаметром 1,2 мм (табл. 3) у захисній газовій суміші $\mathrm{M} 12\left(98 \% \mathrm{Ar}+2 \% \mathrm{CO}_{2}\right)$.

Перший валик було наплавлено без додавання ВВП, п'ять наступних валиків наплавлялись в канавки з попередньо закладеними ВВП різної питомої ваги. В якості ВВП застосовувались вуглецеві тканини марки 24К-1000-80, поверхневої щільності

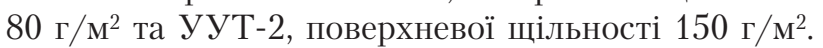
Питома вага вуглецевих закладок визначалась шля- 
Хімічний склад зварювального дроту

\begin{tabular}{|c|c|c|c|c|c|c|c|c|c|}
\hline Елемент & $\mathrm{C}$ & $\mathrm{Si}$ & $\mathrm{Mn}$ & $\mathrm{P}$ & $\mathrm{S}$ & $\mathrm{Cr}$ & $\mathrm{Ni}$ & $\mathrm{Mo}$ & $\mathrm{Cu}$ \\
\hline$\%$, мас. & 0,06 & 0,8 & 6,7 & 0,02 & 0,01 & 18,2 & 8,1 & 0,1 & 0,2 \\
\hline
\end{tabular}

хом їх зважування на аналітичних вагах ВЛР-200 та наступного ділення визначеної маси закладки на довжину наплавленого валика.

Після наплавлення з пластини вирізались методом гідроабразивного різання зразки для металографічних досліджень.

Вимірювання мікротвердості проводили на цифровому мікротвердоміри «TimeGroupInc MHV-1000», дослідження мікроструктури наплавленого металу проводили на оптичному металургійному мікроскопі «MeijitechnoIM 7000». Перед дослідженням зразки піддавалися травленню в суміші концентрованих азотної і плавикової кислоти (суміш, що містить 20\% (за обсягом) азотної і $5 . . .10 \%$ плавикової кислоти).

\section{Результати досліджень}

Мікротвердість наплавленого металу визначалась у двох взаємно перпендикулярних напрямках - по ширині та по висоті валика (рис. 1, б) 3 кроком вимірювань 60 мкм. Загальна кількість вимірювань в кожному координатному напрямку коливалась від 11 до 20, залежно від розмірів валика. В табл. 4 наведено мінімальні, максимальні та середньоарифметичні значення мікротвердості в кожній серії вимірювань, що вказують на суттєве зростання твердості наплавленого металу при збільшенні питомої ваги ВВП.
Металографічні дослідження також показали суттєвий вплив ВВП на мікроструктуру наплавленого металу. Метал, наплавлений дротом ESAB OK Outrod 16.95 без застосування ВВП, має типову коміркову будову аустенітного шва з мінімальною часткою фериту (рис. 2, а). Зі збільшенням питомої ваги ВВП частка феритної фази поступово збільшується (рис. 2, б, в), відбувається перехід до комірково-дендритної форми первинних кристалітів (рис. 2, г, д). Будова валика, наплавленого з найбільшою питомою вагою ВВП біля 7 мг/мм схожа на литу структуру високохромистого чавуну (рис. 2, е) 3 протяжними виділеннями цементитної складової (рис. 3).

Побудована за даними табл. 4 графічна залежність мікротвердості наплавленого аустенітного металу від питомої ваги внесеної ВВП представлена на рис. 4. За результатами лінійного регресійного аналізу методом Фасано-Віо [12] вона може бути виражена параметричним рівнянням:

$$
\mathrm{HV}=218+25,5 \times \mu
$$

де HV - очікувана середня твердість наплавленого металу в одиницях Вікерсу; $\mu$ - питома вага закладеної у розкрий крайок ВВП, мг/мм.

Таблиця 4

Мікротвердість (HV0,2) наплавленого металу, залежно від питомої ваги ( $\mu$ ) ВВП

\begin{tabular}{|c|c|c|c|c|c|c|}
\hline \multirow{2}{*}{$\mu, \mathbf{м г} / \mathbf{м м}$} & \multicolumn{3}{|c|}{ По ширині валика } & \multicolumn{3}{|c|}{ По висоті валика } \\
\hline & $\min$ & $\max$ & cep. & $\min$ & $\max$ & cep. \\
\hline- & 205 & 274 & 235 & 207 & 246 & 224 \\
\hline 0,88 & 209 & 236 & 219 & 206 & 245 & 223 \\
\hline 1,85 & 243 & 296 & 264 & 257 & 281 & 272 \\
\hline 2,77 & 273 & 308 & 294 & 291 & 314 & 296 \\
\hline 3,31 & 292 & 384 & 313 & 294 & 348 & 307 \\
\hline 7,03 & 355 & 423 & 381 & 345 & 499 & 395 \\
\hline
\end{tabular}




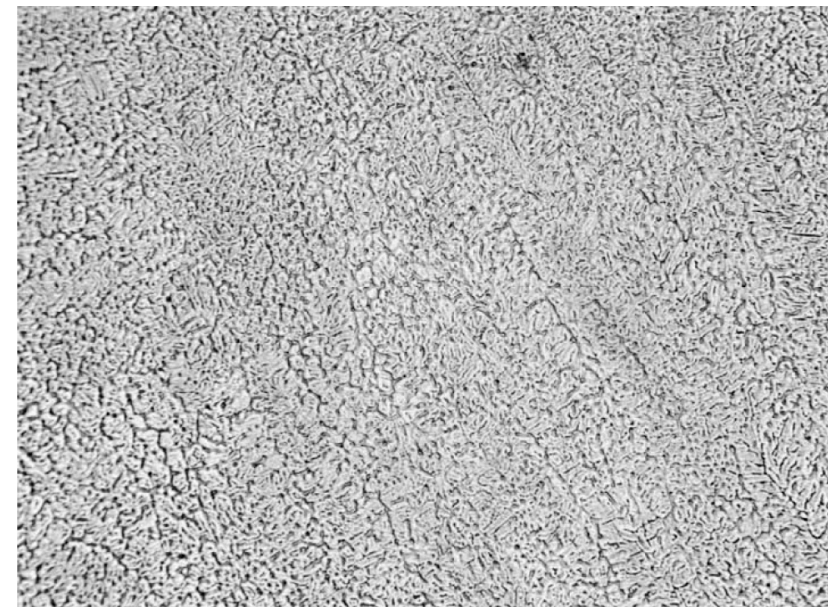

a
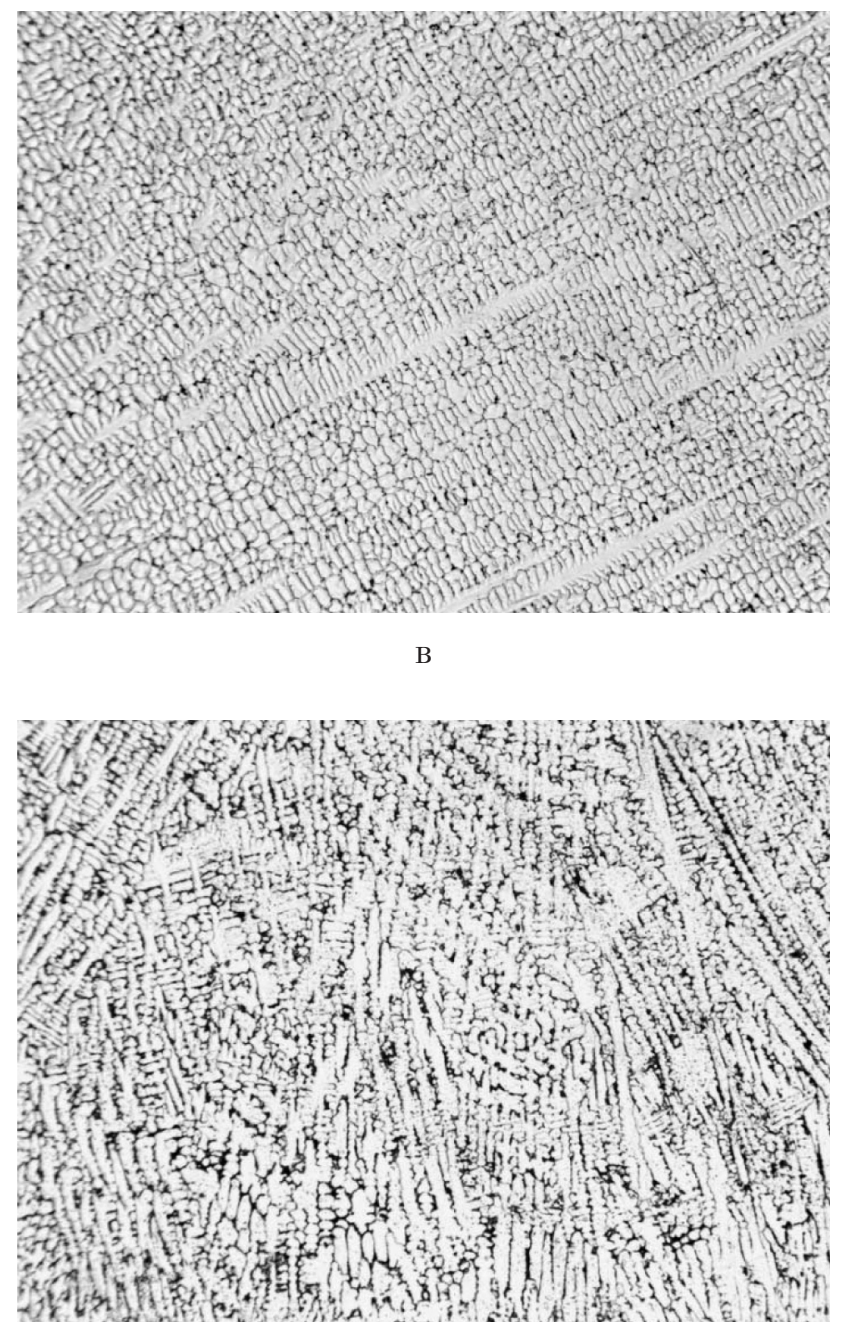

д

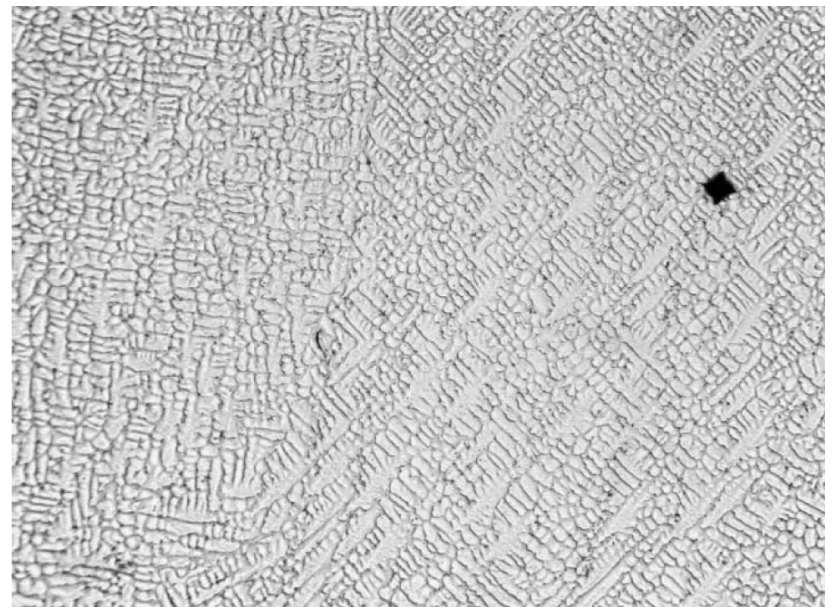

б

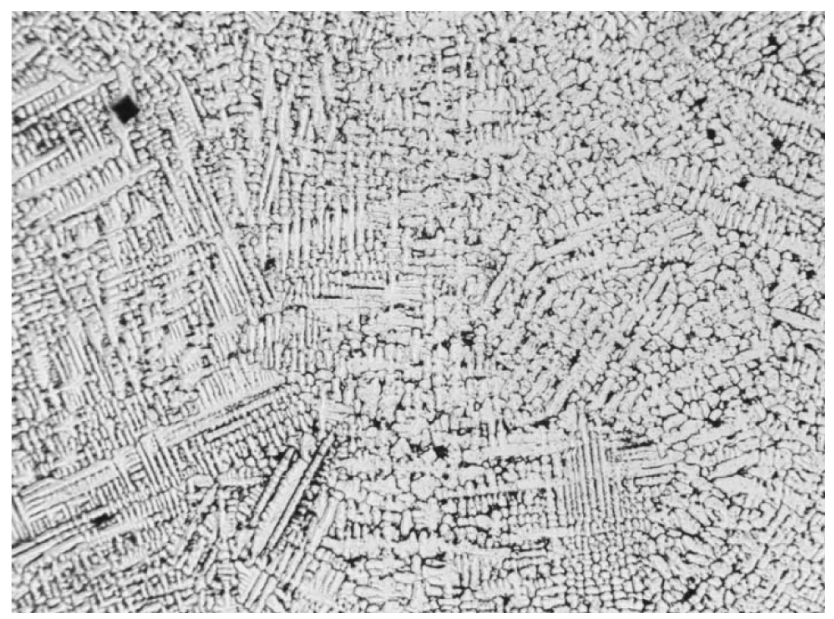

Г

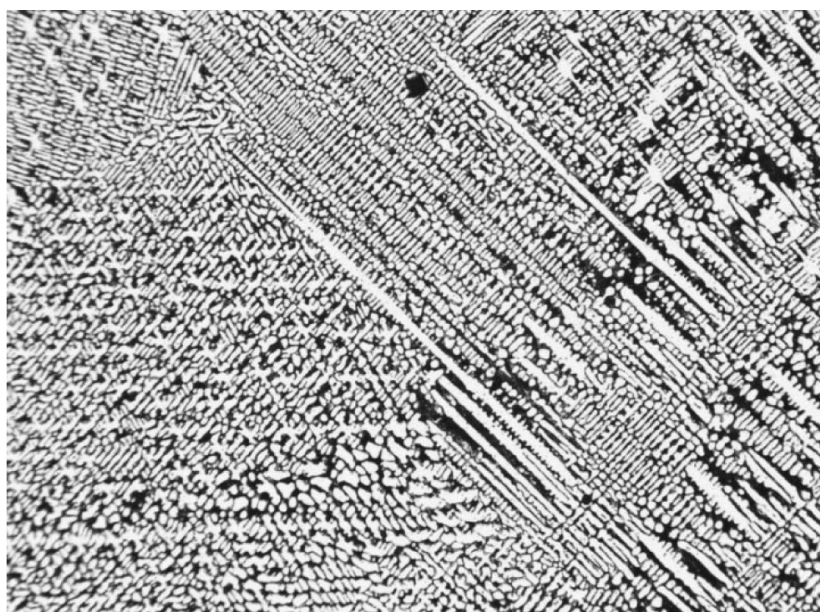

e

Рис. 2. Мікроструктура (×100) наплавленого дротом ESAB OK Outrod 16.95 металу без додавання ВВП (а) та з введенням у шов 0,88 (б), 1,85 (в), 2,77 (г), 3,31 (д), 7,03 (е) мг/мм ВВП 


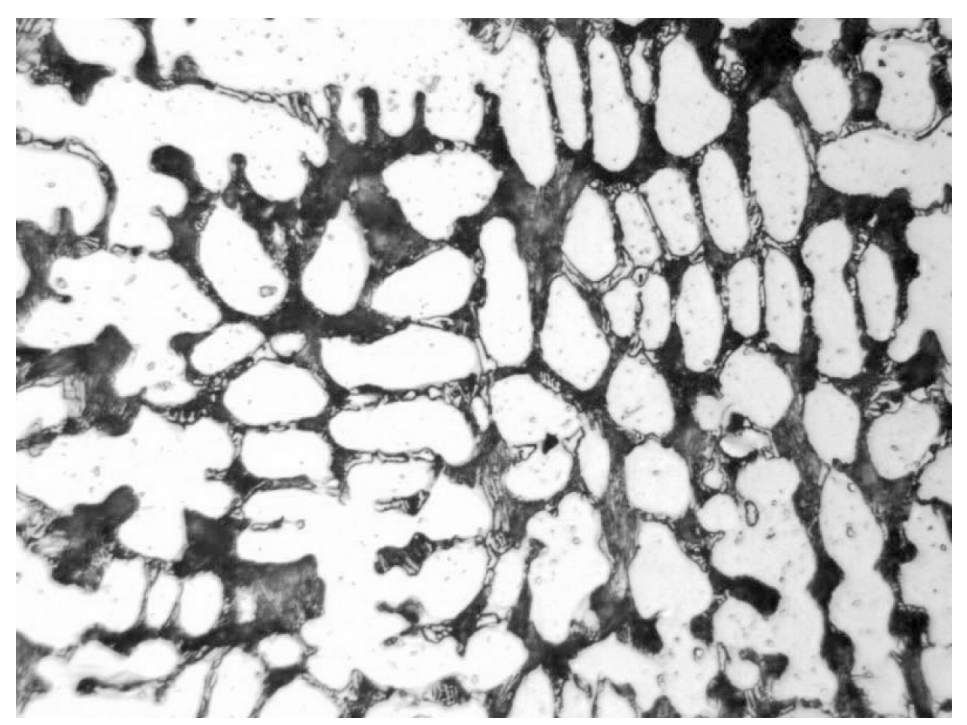

Рис. 3. Мікроструктура (×500) наплавленого дротом ESAB OK Outrod 16.95 металу з додаванням 7,03 мг/мм ВВП

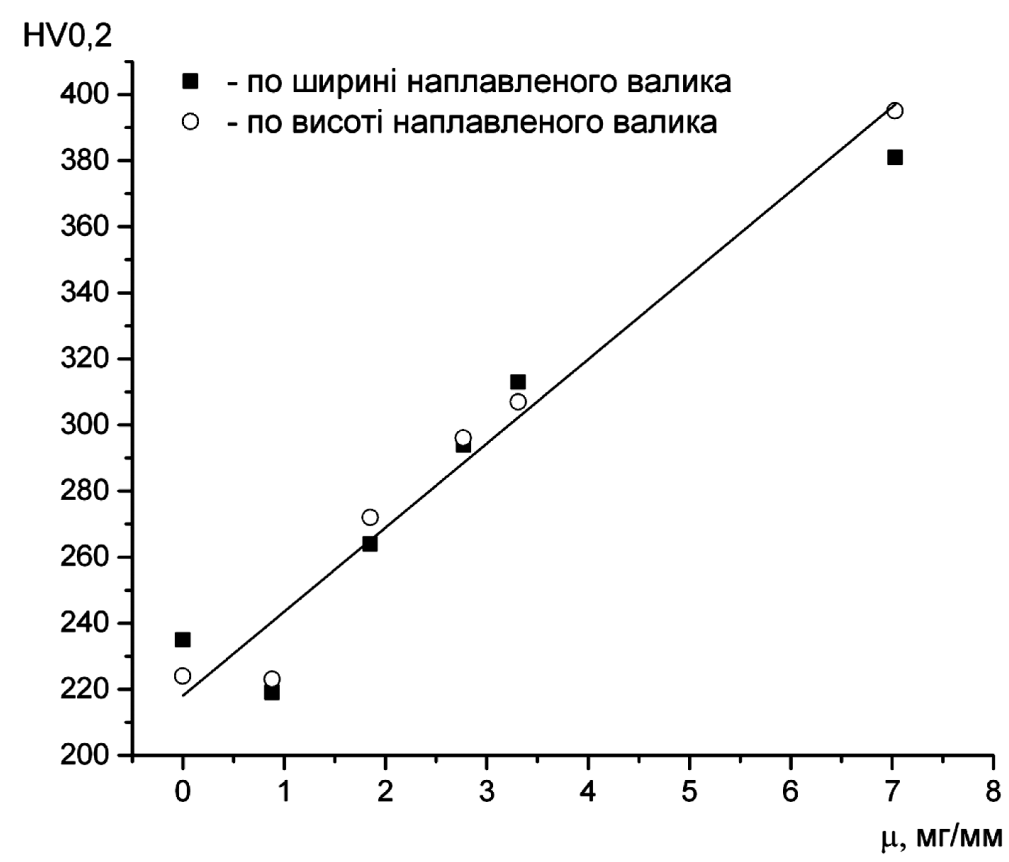

Рис. 4. Вплив питомої ваги ВВП на середню твердість металу наплавленого дротом ESAB OK Outrod 16.95

\section{Висновки}

1. Застосування вуглецевої волокнистої присадки (ВВП) принципово дозволяе збільшити твердість металу шва, наплавленого низьковуглецевими хром-нікель-марганцевими дротами аустенітного класу.

2. Збільшення питомої ваги внесеної в наплавлений метал ВВП підвищує частку феритної фази в ньому та змінює коміркову форму первинних кристалітів на комірково-дендритну.
3. ВВП питомою вагою біля 7 мг/мм обумовлює виникнення яскраво вираженої двофазної структури шва з протяжними виділеннями цементиту та підвищує твердість наплавленого металу в 1,6...1,8 разів у порівнянні з твердістю металу, що наплавлявся штатним аустенітним дротом без ВВП.

4. Залежність твердості наплавленого дротами типу G $188 \mathrm{Mn}$ металу від питомої ваги внесеної ВВП має лінійний характер та може бути описана параметричним рівнянням. 
5. Завданнями подальших дослідів може бути оцінка впливу ВВП на опірність металу шва до тріщиноутворення та оптимізація способів виготовлення та введення ВВП в зварний шов.

\section{Література}

[1] Сливінський О. А. Структура та властивості зварних з'єднань броньових сталей закордонного виробництва / О. А. Сливінський, С. П. Бісик, О. В. Чернозубенко // Технологические системы. - 2016. № 3(76). - С. 103-112.

[2] Быков А. Н. Исследование сварного шва броневой стали БТ-70Ш / А. Н. Быков, А. Д. Мельник, А. Е. Проворная // Вестник бронетанковой техники. - 1981. - № 1. - С. 47-49.

[3] Reddy G. M. Weldability studies of high-strength lowalloy steel using austenitic fillers / G. M. Reddy, T. Mohandas, G. R. N. Tagore // Journal of Materials Processing Technology. - 1995. - Vol. 49. - pp. 213-228.

[4] Cabrilo A. Weldability of High Hardness Armor Steel / A. Cabrilo, K. Geric // Advanced Materials Research. 2016. - Vol. 1138. - pp. 79-84.

[5] Сливінський О. А. Проблеми виготовлення зварних бронекорпусів вітчизняних бойових броньованих машин / О. А. Сливінський, С. П. Бісик, І. Б. Чепков, М. І. Васьківський, О. В. Чернозубенко // Озброєння та військова техніка. - 2017. - № 4(16). - С. 29-38.

[6] Клещев Э. Н. Новые электроды для повышения противопульной стойкости сварных швов / Э. Н. Клещев, В. П. Маркина, А. Г. Махортова, Л. А. Фридлянд // Вестник бронетанковой техники. - 1976. - № 4. C. $47-48$.
[7] Balakrishnan M. Effect of buttering and hardfacing on ballistic performance of shielded metal arc welded armour steel joints / M. Balakrishnan, V. Balasubramanian, G. M. Reddy, K. Sivakumar // Materials and Design. - 2011. - Vol. 32. - pp. 469-479.

[8] Klimpel A. Ballistic resistance of nanostructured and gradient surface layers of protective modules of armour surfaced using the GMA method / A. Klimpel, K. Luksa, M. Burda // Welding International. - 2014. - Vol. 28, No. 5. - pp. 339-344.

[9] Сливинский А. А. Влияние наноразмерных инокулянтов на структуру и свойства метала шва, выполненного проволокой аустенитного класса / А. А. Сливинский, А. В. Нетяга // Технологические системы. - 2017. - № 3(80). - С. 49-55.

[10] Савуляк В. І. Вплив мікроструктури високовуглецевих шарів, отриманих методом електродугового наплавлення з використанням вуглецевих волокнистих матеріалів, на параметри зносостійкості в умовах абразивного середовища / В. І. Савуляк, В. Й. Шенфельд, С. О. Панасюк // Проблеми трибології. 2015. - № 3, С. 105-112.

[11] Савуляк В. І. Вплив мікроструктури високовуглецевих шарів, отриманих методом електродугового наплавлення з використанням вуглецевих волокнистих матеріалів, на параметри зносостійкості в умовах сухого тертя ковзання / В.І.Савуляк, В. Й. Шенфельд, С. О. Панасюк // Наукові нотатки, вип. 49, ч. 1. Луцьк, 2015 - С. 139-143.

[12] Fasano G. Fitting straight lines with errors on both coordinates / G. Fasano, R. Vio // Newsletter of Working Group for Modern Astronomical Methodology. Sept. 1988. - No. 7. - pp. 2-7.

Slyvinskyy O. A., Bornikov A. S.

National Technical University of Ukraine «Igor Sikorsky Kiev Polytechnic Institute». Ukraine, Kiev

\author{
EFFECT OF CARBON FIBER FILLER ON STRUCTURE \\ AND HARDNESS OF AUSTHETIC WELD METAL DEPOSIT
}

The possibility of increasing the hardness of the weld metal, deposited with low-carbon Cr-Ni-Mn austenitic electrode wires, by applying a carbon fiber filler is specified. The influence of the carbon fiber filler on the microstructure of the deposited weld metal is determined. According to the results of experimental studies, it is assumed that the dependence of the hardness of the welded with type G $188 \mathrm{Mn}$ wire weld metal on the specific weight of the carbon fiber filler is linear and can be described by the parametric equation proposed in the work. [dx.doi.org/10.29010/083.9]

Keywords: Gas metal arc welding; carbon fiber filler; high hardness armor steel; austenitic electrode wire; microhardness; microstructure. 


\section{References}

[1] Slyvinskyy O. A., Bisyk S. P., Chernozubenko O. V. Structure and properties of welded joints of armor steels foreign production // Technological systems. - 2016. - No 3(76). - pp. 103-112.

[2] Bykov A. N., Melnik A. D., Provornaya A. E. Investigation of welded armor steel BT-70Sh // VBT. - 1981. - No 1. pp. 47-49.

[3] Reddy G. M. Weldability studies of high-strength low-alloy steel using austenitic fillers / G. M. Reddy, T. Mohandas, G. R. N. Tagore // Journal of Materials Processing Technology. - 1995. - Vol. 49. - pp. 213-228.

[4] Cabrilo A. Weldability of High Hardness Armor Steel / A. Cabrilo, K. Geric // Advanced Materials Research. - 2016. Vol. 1138. - pp. 79-84.

[5] Slyvinskyy O. A., Bisyk S. P., Chepkov I. B., Vaskivskyi M. I., Chernozubenko O. V. Problems of manufacturing welded armored hulls of domestic armored combat vehicles // Weapons and military equipment. - 2017. - No 4(16). pp. 29-38.

[6] Kleschev E. N., Markina V. P., Mahortova A. G., Fridland L. A. New electrodes for increasing the bulletproof resistance of welded joints // VBT. - 1976. - No 4. - pp. 47-48.

[7] Balakrishnan M. Effect of buttering and hardfacing on ballistic performance of shielded metal arc welded armour steel joints / M. Balakrishnan, V. Balasubramanian, G. M. Reddy, K. Sivakumar // Materials and Design. - 2011. - Vol. 32. pp. 469-479.

[8] Klimpel A. Ballistic resistance of nanostructured and gradient surface layers of protective modules of armour surfaced using the GMA method / A. Klimpel, K. Luksa, M. Burda // Welding International. - 2014. - Vol. 28, No. 5. - pp. 339-344.

[9] Slyvinskyy O. A., Netyaga A. V. Influence of nano-dimensional inoculators on structures and properties of metal squams implemented by austenite class wire // Technological systems. - 2017. - No 3(80). - pp. 49-55.

[10] Savulyak V. I., Shenfeld V. Y., Panasiuk S. O. Effect of high-carbon layer microstructure obtained by arc welding using carbon fiber materials, the parameters of durability to abrasion environment // Problems of Tribology. - 2015. - No 3, pp. 105-112.

[11] Savuliak V. I., ShenfeldV. I, Panasiuk S. O. Vplyv mikrostruktury vysokovuhletsevykh shariv, otrymanykh metodom elektroduhovoho naplavlennia z vykorystanniam vuhletsevykh voloknystykh materialiv, na parametry znosostiikosti v umovakh sukhoho tertia kovzannia // Naukovi notatky, Vol. 49, Part 1. - Lutsk, 2015. - pp. 139-143.

[12] Fasano G. Fitting straight lines with errors on both coordinates / G. Fasano, R. Vio // Newsletter of Working Group for Modern Astronomical Methodology. - Sept. 1988. - No. 7. - pp. 2-7. 